\title{
The Impacts of well Planned Recruitment and Selection Process on Corporate Performance in Nigerian Banking Industry (A Case Study of First Bank Plc 2004-2011)
}

\author{
MUSTAPHA, Adeniyi Mudashiru (Ph.D) \\ C/ODEPARTMENT OF BUSINESS ADMINISTRATION, \\ UNIVERSITY OF ILORIN, ILORIN \\ NIGERIA. \\ E-mail: mustymud@yahoo.com
}

\author{
ILESANMI, O.A. (Ph.D) \\ DEPARTMENT OF BUSINESS ADMINISTRATION, \\ OSUN STATE UNIVERSITY OSOGBO, \\ NIGERIA \\ E-mail: drilesanmi1@yahoo.com
}

\author{
AREMU, M. (Ph.D) \\ DEPARTMENT OF BUSINESS ADMINISTRATION, \\ UNIVERSITY OF ILORIN, ILORIN \\ NIGERIA. \\ E-mail: aremuilalaa@yahoo.com
}

DOI: 10.6007/IJARBSS/v3-i9/251 URL: http://dx.doi.org/10.6007/IJARBSS/v3-i9/251

\begin{abstract}
A sound recruitment programme logically follows a well drawn-up manpower plan. In fact, the quality of the present manpower plan as indeed of every present decision of the organization depends upon the quality of recruitment policies and practices. This paper examines recruitment and selection process. It identifies a typical source by separating recruitment into internal and external and discussed the advantages of each method. The analytical tools used in this study were regression analysis and analysis of variance (ANOVA) to determine the relationship between a well planned recruitment and selection process on corporate performance. Findings revealed that there is a significant relationship between recruitment and selection based on merit and organizational performance; that effective recruitment and selection is a key to organizational commitment; that a well planned recruitment and selection contributes to organizational performance.

The paper concludes by drawing the danger potends by poor recruitment and selection as poor recruitment could lead to selection of poor applicants.
\end{abstract}


Keywords: Recruitment, Selection, Psychological Test, Motivation, Education

\section{INTRODUCTION}

The position of a country's economy determines the rate of employment of personnel and hence upon recruitment and selection. Uncertain economic may cause people to remain in their present jobs and particularly discourage them from moving elsewhere especially when they do not know what is obtainable and what is not. In this case, growth in industries may be hampered as it is difficult to obtain the experience persons required. But in a stable economy, the forces of the interaction of demand and supply will generally encourage the movement of labour and employment of new personnel that can contribute positively to the organization's aims and objectives.

The process of acquiring and selecting personnel is the primary concern of this paper. Recruitment and selection begins with clear statement of objectives based on the types of knowledge, skills, abilities and other characteristics that an organization needs (Casio 2002).

The process of searching for a new employee is customarily initiated by a manager who decides that he needs to add to his staff or to replace someone who is leaving the organization. Commonly he makes a written request to the personnel department stating that he wishes to hire someone to fill a vacancy. The position to be filled is defined in terms of its job description and its job specification. The hiring activity should be integrated with the human resource plan of the company. These plans should forecast department that are expected to grow and those that may decline. There should be a skill inventory so that present employees can be matched with job openings to provide for transfers and promotions.

It almost goes without saying that the caliber of the work force of an organization largely determines its strength and its success as an enterprise. The employment manager must have a good understanding of the labour market and how it functions, sources of personnel, recruitment methods and selection procedures.

Whatever method used depends on the organization, but there are basic processes which most organizations go through.

The objectives of this paper therefore are;

i. To examine recruitment and selection process

ii. To identify a typical source by separating recruitment into internal and external

iii. To discuss the advantages and disadvantages of each method

iv. To determine whether a well planned recruitment and selection process has impact on corporate performance.

v. To highlight the danger potends by poor recruitment and selection processes.

\section{RECRUITMENT}

According to Weihrich and Koontz (1994), recruitment involves attracting of candidates to fill the positions in an organizational structure. Before recruiting begins, the position's requirements which should relate to the task must be clearly identified. 
Stonner, Freeman and Gilbert (2000) stated that the purpose of recruitment is to provide a group of candidate that is large enough to let managers select the employees they need.

Hannagan (1995) sees recruitment as the first process of filling vacancies. He goes further to say that the process involves the examination of the requirements for filling the vacancy (particularly in relation to job and person specifications); consideration of the sources of suitable candidates, drafting job advertisements and selecting media suitable to carry them; assessing appropriate salary levels for employees; and arranging interviews and other aspects of selection.

Ejiofor (1989) was of the view that recruitment consists of seeking out and attracting who, while filling positions required for the successful implementation of the objectives of an organization, will also realize their personal objectives. According to him, the aim of recruitment goes beyond mere filling of vacancies to include individual development and achievement.

llesanmi (1997) defined recruitment as the process of attracting individuals in sufficient numbers and with appropriate qualifications and encouraging them to apply for jobs with the organization. According to him, recruitment is knowing what staff are required and where to get them.

Nwachukwu (1992) considers recruitment to involve all prospective applicants for the job position in the organization. He is of the view that a good recruitment programme is one that is properly planned and well operated. He concludes that poor recruitment efforts could lead to the selection of poor applicants because positions are to be filled quickly.

Selection involves making decisions about people. Where there are several job applicants for an opening, managers must decide which is the most qualified. Selection is the process of identifying those recruited individual will best be able to assist the firm in achieving organizational goals (Ilesanmi 2005).

\section{METHODS AND SOURCES OF RECRIUTMENT}

Flippo (1984) opined that the sources of employees can be classified into two types, internal and external.

The methods of recruiting will depend upon the source of recruitment the organization intends to utilize (Ejiofor 1989). Where an organization decides on a policy of recruitment from within, then the methods of recruitment will include job posting on public boards in order to inform all employees and so allow open competition; the secret review of the records of employees and giving the jobs to chosen employees; and finally, announcement to employees and unions that there are vacancies and that new hands will be welcome. Employees and unions are then in a position to inform friends, relations and colleagues. These methods of recruitment will work well for filling low-paid positions in the organization.

It is often argued that a policy of internal recruitment is superior to a policy which looks outside the boundaries of the organization because it allows individual development. Employees, it is said, have a right to advance in their jobs and therefore should be given first consideration when job occur. Filling a job opening from within the firm has the advantages of stimulating preparation for possible transfer or promotion, increasing the general level of morale, and providing more information about job candidates through analyses of work 
histories within the organization. An internal search of the computer personnel data bank can flag personnel within minimum qualifications for the job opening. Such system is more compatible with adapting the organization to the needs of individuals.

A job posting system has a number of advantages. From the view point of the employee, it provides flexibility and greater control over career progress. For the employer, it should result in better matches of employee and job, in addition to meeting requirements for equal opportunity for advancement of all employees (Flippo 1984).

While this argument is generally valid, it is well to remember that occasions often arise when existing employees do not possess the skills for the required tasks, or when giving them such skills will entail considerable costs to the organization. It has been argued that, no matter how much a company may design its manpower requirements to take account of internal skill developments, it still becomes necessary to bring in new talents into the organization through external recruitment.

Hannagan (1995) listed the following advantages of filling the vacancy internally rather than externally;

- Better motivation of employees because their capabilities are considered and opportunities offered for promotion.

- Better utilization of employees, because the organization can often make better use of their abilities in a different job;

- Greater reliability as compared with an external recruitment because a present employee is known more thoroughly than an external candidate;

- That a present employee is made likely to stay with the organization than an external candidate.

Stonner, Freeman and Gilbert (2000) identified three advantages of an organization policy to recruit from within.

First, individuals recruited from within are already familiar with the organization and its members, and this knowledge increases the likelihood that they will succeed. Secondly, a promotion from within policy fosters loyalty and inspires greater effort among organization members. Finally, it is usually less expensive to recruit or promote from within than to hire from outside the organization. Certain disadvantages to internal recruitment were also recognized. It limits the pool of available talent. In addition, it reduces the chance that fresh view points will enter the organization, and it may encourage complacency among employees who assume seniority ensures promotion.

Ejiofor (1989) posits that the methods of external recruitment are varied and depending upon the category of staff being solicited for. The methods, according to him usually include advertising in the mass media-newspapers, radio, television, trade magazines and journals, sender recruiters to colleges and universities, utilizing employment agencies and head hunting in conferences and seminars.

Another method of external recruitment is relying upon the name and image of the organization in the community to attract unsolicited applications by post, and by applicants presenting themselves at the employment office of the organization. 'Head-hunting', which consists of sending recruiters to conferences and seminars or other such places, is often used for attracting high talented and skilled staff away from the organization in which they are 
employed. This usually works well with professional and managerial personnel. This class of personnel can also be attracted through advertisements in the mass media or through direct recruiting on the campuses of higher institutions. Hannagan (1995) states the advantages of head hunting as follows:

- Head hunters should possess expert knowledge of the salary levels and fringe benefits necessary to attract good caliber candidates. Also, they will analyze the vacancy and offer an opinion about the type of person required, will conduct initial screening and minister psychometric test, etc. this saves the client many administrative costs and advertising expenses.

- Possibly, top managers already in employment will not bother to read job advertisements, newspapers and other conventional media and hence cannot be reached by these means.

- Senior managers prepare to consider a move sometimes make this known to leading head hunters, even though they would not openly apply to competing companies.

-If a targeted candidate does not want the job, he or she may suggest someone else who is equally suitable and who may in fact be interested.

-Recruiting firms are assured that candidates presented to them will almost certainly be well equipped for the vacant position.

-The anonymity of the recruiting organization is reserved until the final stages in the procedure.

In carrying out external recruitment, it is important that where advertisements are used, all the relevant information relating to the job and the organization is given to prospective candidates. Blind advertisements which ask applicants to respond to addresses other, than those of the employees themselves place some applicants in a situation where they subsequently discover that they are responding to advertisements placed by the organization in which they are currently employed. It is also important that recruiters as well as the advertisement of jobs do not oversell the jobs and the organisation. Ejiofor (1989) concludes that such recruitment will be justified to the extent that it enables the organization to have an injection of new ideas or to deal with shortages in skills and efforts which current employees cannot supply.

An organization's decision on whether to adopt internal or the external one depends on so many factors. Nwachukwu (1992) listed the factors that influence the type of recruitment to include the following;

- The quality and number of staff and positions to be filled.

- The financial position of company. Well-to-do companies can afford to travel overseas, advertise in all new media, and even employ the services of professional agencies.

- Availability of required staff within the country.

- Peculiar circumstances of the staff required. Some quality staff required are often bonded, have children at school or other commitments that 
would make the assumption of duty in the company not feasible in the immediate present.

In addition, the following factors have also been identified as factors that determine sources of recruitment;

- Organizational policy regarding recruitment.

- The availability of the required staff within the organisation and its effect on the overall organizational efforts.

- The level of position to be filled.

- The number of job positions to be filled.

\section{SELECTION PROCESS:}

Stonner, Freeman and Gilbert (2000) see the selection process as the mutual process whereby the organisation decides whether or not to make a job offer and the candidate decides whether or not to accept it. In the view of Ejiofor (1989), selection is the process of choosing from the pool of potential employees available those jobs in terms of qualified job and organisation requirements. Organisation requirements will include the need to take account of the expectations of existing employees, whether for example, the new employee will find acceptance with existing employees. Hannagan (1995) defines selection as the assessment of candidates for vacant jobs and the choice of most suitable people. Selection is the oldest function of public personnel administration (Shafritz, Russell and Borick20Q7).

One thing that stands clear from the above is that, selection is usually made from among many applicants that have applied for positions and meet the organization requirement.

Selection involves matching the requirements of a job with attributes of candidates. This is facilitated by drafting a 'person specification' defining the background, education, training, personality and other characteristics of the ideal candidate. The person described may not exist, but the process of drafting a person specification creates a standard against which candidates can be compared (Boertist and Mojboom 1989).

Speaking in the same vein Weihrich and Koontz (1994) expressed that selecting a manager is choosing from among the candidates the one who best meets the position requirements.

Nwachukwu (1992) sees selection as a systematic effort to identify the most suitable candidates to fill an identified vacancy. He is of the view that selection is a very important process which requires planning and objectivity and that, no organisation is better than the people who make it up. He concludes by saying that a selection exercise should not be left in the hands of amateurs or the less initiate in the art of selection.

Flippo (1984) sees selection process as hiring procedure. According to him, in the hiring procedure varying methods are used to discover significant information about an applicant, which can then be compared with the job specification. He is of the opinion that there is no standard procedure adopted by all firms, the following is an example of a popular method:

Initial or preliminary interview - This initial interview is usually quite short and has as its objective the elimination of the obviously unqualified. In many instances it is a standing interview conducted at a desk or railing.

The more obvious facts and impressions are the type generally obtained in an interview. Appearance and facilities in speech are evaluated. Applicants are often asked 
why they are applying for a job with this particular organisation. Salary requirements are ascertained.

An idea of education and experience can be obtained by knowing the time applicants finished in school and the names of job previously held. Many firms do not bother to initiate any paper work at this early stage. If the applicant appears to have any chance of qualifying for existing job openings, he or she is given the application blank to complete.

Application Blank - One of the general principles of hiring procedures is to assign each step information objectives that can be best obtained by the methods of that particular step. Factual information should be obtained by means of an application blank. We should not automatically assume that all information written on the blank by the applicant is correct.

References - The purpose of the reference check is to obtain information about past behaviour of applicants and to verify the accuracy of information given on the application blank. Cole (2005) expressed that most public sector organisation take up references before short listed candidates are called for interview; while private sector organisation tend to take them up after the candidate has been interviewed and a provisional offer of appointment made. The most common method of checking was a combination of letters and telephone calls. Letters of reference carried by the applicant are of little value; one knows what is in them.

Psychological Tests - The next step in the procedure outlined above is that of testing. Most of the larger companies that can afford to have a more detailed and accurate selection procedure do utilize some form of employment testing. It is the smaller company that frequently does not bother with tests, but places great reliance upon the interview.

Interviewing - Interviewing is probably the most widely used single method of selection. A substantial amount of subjectivity, and therefore/ unreliability, is to be expected from interviewing when used as a tool of evaluation. One human being is evaluating another in somewhat strained and artificial circumstances. The specific sources of unreliability are several in numbers. First, the interview is allocated information objectives that cannot be obtained otherwise; this it deals with intangible goals such as assessing leadership role fit, and inner motivation. Secondly, much research of specific sources of subjectivity has demonstrated the following: (1) those interviewed immediately after the candidates are appraised more favourably; (2) excessive weight is given to unfavourable information, with only one negative item leading to rejection in about 90 percent of the cases in one study; (3) interviewer stereotyping exists with more females recommended for such jobs as editorial assistant and more males for personal technician; (4) interviewers sometimes make a decision very early and conduct the rest of the interview searching for substantiating information; (5) when favourable information is received to unfavourable, the applicant fares better; $(6)$ the greater the number of job vacancies the more favourable the applicant evaluation and, (7) interviewers are often affected by appearance and non-verbal clues having little to do with job performance.

\section{Types of Interviews:}

In general, there are two types of interviews, guided and unguided. Alternative titles sometimes used are "directed and non-directed" and "patterned and unpatterned". In the guided interview, a list of question is prepared based on an analysis of the job specification. 
Such a list is quite helpful to the untrained interviewer, but with the passage of time and development of skill, one tends to depart from this detailed pattern.

The unguided interview is more often used in situations other than hiring, such as counseling, processing of grievances, and exit interviews. This type of interview is largely unplanned, and the interviewee does most of the talking. The theory of the unguided interview is that the interviewee will reveal more of her or his desires and problems. The greater use of this type is by skilled counselors in seeking to help disturbed people. Advice and reassurance are avoided, and listening is emphasized. Although the typical employment interview is guided, the use of the unguided approach for higher types of job opening is not unknown. More time is devoted to interviewing the candidate frequently by many different interviewers.

Another basis for classifying interviews is the situation in which the interview is conducted. We are discussing here primarily the employment interview. In addition to this type, there is the counseling interview, the merit-rating or appraisal interview, the grievance interview, and the exit interview. A list of this kind emphasizes the fact that the interview is a basic management tool that is used in many situations.

Hannagan (1995) suggests the following rules to be followed when conducting interviews.

(1) Opening remarks should be supportive and controversial.

(2) Questions which simply ask for repetition of information already provided on application forms should be avoided. Rather, the interviewer should seek supplement any information to probe in depth the candidate's potential.

(3) Detailed note taking by interviewers is advisable because it's disturbing effects on the interviewee. Candidates should be assessed immediately after their interviews. Otherwise, important points in earlier interviews will be forgotten in the final end ofsession appraisal,

(4) Open ended questions such as what made you decide to do that? or why did you enjoy that type of work? are usually more productive in obtaining information than direct queries. Generally, worded questions invite the candidate to discuss feelings, opinions and perceptions of events. Simple Yes/No questions will not draw out the candidate's opinion. Interviewers should not make critical or insensitive remarks during the interview.

(5) Interviewers should not compare candidates with themselves

(6) Only Job-relevant questions should be asked.

(7) The halo-effect i.e. assuming that because a candidate possesses one desirable characteristics (smart appearances or a good speaking voice, for example), that he/she must be equally good in all other areas, must not be allowed to influence the selection.

(8) "Revealing" questions should not be asked. A revealing question discloses attitudes and beliefs held by the questioner. An example would be "I" like watching football, don't you?

(9) Inappropriate criteria must not be applied. This could involve, for example, males who interview females associating attractive physical appearance with work, ability, or appointing people the interviewer knows socially. 
(10) Interviewers should not behave in a pompous manner. This wastes time and contributes nothing to the quality of the interview.

(11) Interview panels should be as small as possible. Over large panels create unhelpful atmospheres, and panel members might ask irrelevant and disconnected questions.

\section{Approval by the Supervisor:}

Following the outlined procedure, we should now be of the opinion that a candidate who has successfully completed all steps thus far should be hired. At this point in the process, a third interview is conducted. The information objectives of this interview may well overlap those of the preceding one. This overlap is not undesirable for at least two reasons. First, the organizational relationships often require that the supervisor be given the right to pass upon personnel; otherwise he or she cannot be held accountable for their performance. Secondly, the qualities that are generally appraised in an interview are highly intangible, such as personality, ability to get along with others and leadership potential. In such matters, it is helpful to have an appraisal by both the staff employment interviewer and the supervisor, who is better acquainted with the actual Job conditions and the type of personnel at present in the department.

\section{Physical Examination:}

The physical examination is an employment step in most businesses. It can vary from a very comprehensive examination and matching of an applicant's physical capabilities to job requirements, to a simple check of general physical appearance and well-being. In the hiring procedure, the physical examination has at least three basic objectives. First it serves to ascertain the applicant's physical capabilities. Can the applicant work standing up? Is his or her eye sight sufficiently keen to meet the job requirement?

The second objective of the examination is to protect the company against unwarranted claims under workers' compensation laws, or against lawsuits for dangers.

\section{METHODOLOGY:}

Primary and Secondary data was used in writing this paper. Questionnaire was carefully structured in selected ten branches and given to staff of First Bank in Lagos, Ibadan, Ilorin, Offa, and Osogbo to elicit responses on the merit, effectiveness and planned recruitment and selection process. First Bank Plc. was used because it is one of the leading commercial banks in Nigeria having over 120 years of effective banking experience. 250 questionnaires were administered of which 240 representing (96\%) were retrieved and used in this paper. The analytical tools utilized in this study were regression analysis and analysis of variance (ANOVA) to test the hypotheses formulated.

\section{Hypotheses Testing}

\section{Data Presentation and Analysis}

\section{Test of Hypothesis One}

Ho: There is no significant relationship between recruitment and selection based on merit and organizational performance. 
$\mathrm{Hi}$ : There is a significant relationship between recruitment and selection based on merit and organizational performance.

\begin{tabular}{|c|c|c|c|c|}
\hline $\mathrm{X}$ & $\mathrm{Y}$ & $\mathrm{XY}$ & $\mathrm{X}^{2}$ & $\mathrm{Y}^{2}$ \\
\hline 5 & 84 & 420 & 25 & 7056 \\
\hline 4 & 96 & 384 & 16 & 9216 \\
\hline 3 & 24 & 72 & 9 & 576 \\
\hline 2 & 24 & 48 & 4 & 576 \\
\hline 1 & 12 & 12 & 1 & 144 \\
\hline 15 & 240 & 936 & 55 & 17568 \\
\hline
\end{tabular}

$r=$

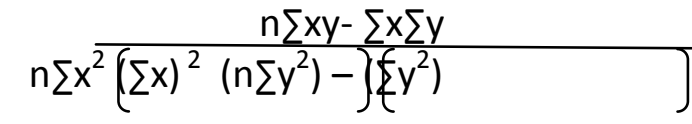

$r$

$=$

$5(936)-15(240)$

$\sqrt{(15}$

$=$

$4680-3600$ $(275-225)(87840-57600)$

$=$

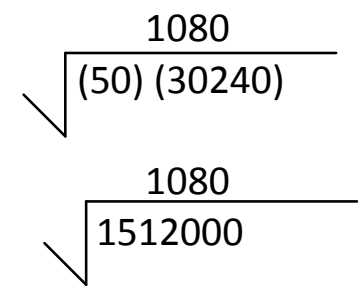

$=$

1080

1229.63

$r=$

0.8783 or $87.83 \%$

\section{Decision Rule}

The alternative hypothesis states that there is a significant relationship between recruitment and selection based on merit and organizational performance as revealed by $r=$ 0.8783 or $87.83 \%$.

\section{Test of Hypothesis Two}

Ho: Effective recruitment and selection is not a key to organizational 
commitment

$\mathrm{Hi}$ : Effective recruitment and selection is a key to organizational commitment

\begin{tabular}{|c|c|c|c|c|}
\hline$X$ & $Y$ & $X Y$ & $X^{2}$ & $Y^{2}$ \\
\hline 5 & 96 & 480 & 25 & 9216 \\
\hline 4 & 108 & 432 & 16 & 11664 \\
\hline 3 & 24 & 72 & 9 & 576 \\
\hline 2 & 6 & 12 & 4 & 36 \\
\hline 1 & 6 & 6 & 1 & 36 \\
\hline 15 & 240 & 1002 & 55 & 21528 \\
\hline
\end{tabular}

$$
\begin{aligned}
& =\frac{n \sum x y-\sum x \sum y}{\left.\sqrt[n]{\left[\sum x^{2}-\left(\sum x\right)^{2}\left(n \sum y\right]^{2}\left[-\left(\sum y^{2}\right)\right.\right.}\right]} \\
& =\quad 5(1002)-15(240) \\
& \sqrt{\left(15(55)-(15)^{2}\right) 5\left[(21528)-\left(240^{2}\right)\right]} \\
& =\quad 5010-3600 \\
& \sqrt{(275-225)(107640-57600)} \\
& =\quad 1410 \\
& \sqrt{(50)(50040)} \\
& =\quad \sqrt{2502000}
\end{aligned}
$$

ANOVA TABLE CALCULATION

\begin{tabular}{|c|c|c|c|c|c|c|}
\hline Year & \multicolumn{2}{|c|}{$\begin{array}{c}\text { Investment In } \\
\text { Technology Fixed } \\
\text { Asset \# } \boldsymbol{b}\end{array}$} & \multicolumn{2}{c|}{$\begin{array}{c}\text { Shareholder's Funds } \\
\#^{`} \boldsymbol{b}\end{array}$} & \multicolumn{2}{c|}{$\begin{array}{c}\text { Profit Before Tax } \\
{ }^{\prime} \boldsymbol{b}\end{array}$} \\
\hline & $\mathrm{X}_{1}$ & $\mathrm{X}_{1}{ }^{2}$ & $\mathrm{X}^{2}$ & $\mathrm{X}_{2}{ }^{2}$ & $\mathrm{X}_{3}$ & $\mathrm{X}_{3}{ }^{2}$ \\
\hline 2011 & 55.352 & 3063.84 & 380.794 & 145004.07 & 68.029 & 4628.0 \\
\hline 2010 & 52.616 & 2768.44 & 350.467 & 122827.12 & 33.154 & 1099.20 \\
\hline
\end{tabular}




\begin{tabular}{|c|c|c|c|c|c|c|}
\hline 2009 & 46.320 & 2145.54 & 351.054 & 123238.91 & 46.110 & 2126.13 \\
\hline 2008 & 29.155 & 850.01 & 339.847 & 115496.00 & 38.020 & 1445.52 \\
\hline 2007 & 16.850 & 283.92 & 77.351 & 5983.20 & 22.097 & 488.30 \\
\hline 2006 & 13.952 & 194.66 & 60.980 & 3718.56 & 16.128 & 260.11 \\
\hline 2005 & 12.108 & 146.60 & 44.672 & 1995.60 & 15.145 & 229.37 \\
\hline 2004 & 9.564 & 91.47 & 38.621 & 1491.60 & 14.106 & 199.0 \\
\hline TOTAL & 235.92 & 9544.48 & 1643.80 & 519755.06 & 252.80 & 10475.63 \\
\hline
\end{tabular}

Sum of square between the group $=\operatorname{ssbg}=\left(\sum x_{1}\right)^{2}+\cdots \cdot\left(n \sum x_{3}\right)^{2}$

$$
\mathrm{n} 1 \quad \overline{\mathrm{N} 1}
$$

Sum of square within the group $=$ ssbw $=\left(\sum x_{1}\right)^{2}-\left(\sum x\right)^{2}+\cdots \cdot \sum(x k)$

$$
\mathrm{n} 1 \quad \mathrm{Nk}
$$

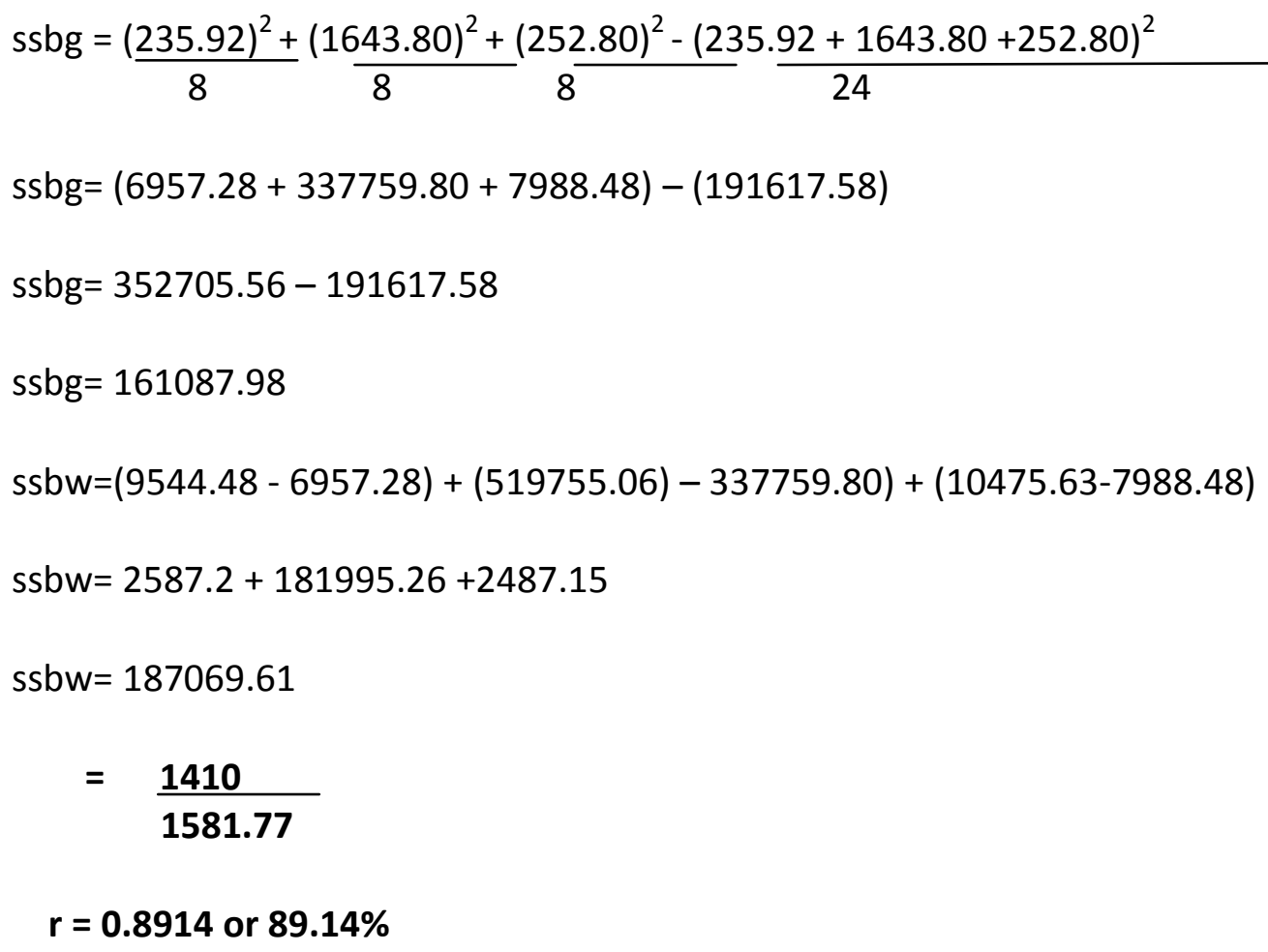

\section{Decision Rule}

The alternative hypothesis states that effective recruitment and selection is a key to organizational commitment, while Ho is rejected. The regression result indicates $r=0.8914$ or $89.14 \%$. 
Effective recruitment and selection in First Bank Plc makes the newly recruited employees to be committed to the bank activities and thereby creating values for the enterprise.

\section{Test of Hypothesis Three}

Ho: Well planned recruitment and selection in First Bank Plc has not contributed to the organizational performance.

Hi: Well planned recruitment and selection in First Bank Plc has contributed to the organizational performance.

In testing hypothesis three, ANOVA was used.

Analysis of ANOVA Table

\begin{tabular}{|c|c|c|c|c|c|}
\hline $\begin{array}{l}\text { Source of } \\
\text { Variation }\end{array}$ & $\begin{array}{l}\text { Degree of } \\
\text { Freedom }\end{array}$ & $\begin{array}{l}\text { Square of } \\
\text { Square }\end{array}$ & Mean of Square & 1 Ratio & F Cal \\
\hline $\begin{array}{l}\text { Between } \\
\text { the group }\end{array}$ & $\begin{array}{c}K-1 \\
3-1=2\end{array}$ & $\begin{array}{c}\text { Ssbg } \\
161087.98\end{array}$ & $\begin{array}{r}\underline{s s b g}=\underline{1601087.98} \\
K-1 \\
\\
=80543.99\end{array}$ & $\begin{array}{l}\underline{\mathrm{msbg}} \\
\mathrm{msbw}\end{array}$ & $\begin{array}{l}0.5 \% \text { level of } \\
\text { significance }\end{array}$ \\
\hline $\begin{array}{c}\text { Within the } \\
\text { group }\end{array}$ & $\begin{array}{c}\mathrm{N}-\mathrm{K} \\
24-3=21\end{array}$ & $\begin{array}{c}\text { Ssw } \\
187069.61\end{array}$ & $\begin{aligned} \frac{S S W}{K-1}= & \frac{187069.61}{21} \\
& \\
& =8908.1\end{aligned}$ & $\begin{array}{l}\underline{80543.99} \\
8908.1 \\
=9.04\end{array}$ & 3.8 \\
\hline Total & $\begin{array}{c}\mathrm{N}-\mathrm{K} \\
24-1=23\end{array}$ & & & & \\
\hline
\end{tabular}

\section{Source: ANOVA Table (Output)}

The variability determine by the difference between the group is 161087.98 which is the result of experimental manipulation while 187069.61 is due to sampling error or other factors. This implies that investment in technology (fixed assets) has improved the effectiveness of recruitment 
and selection in First Bank Plc. Furthermore, 80543.99 is the mean variance estimated for between the group and 8908.1 is the mean variance estimated for within the group.

Since $\mathrm{F}$ ratio which is the final result of ANOVA is greater that $\mathrm{I}$, it means it will be too great to attribute variance in mean to sampling error. Therefore, the difference is attributed to experimental treatment which is the impact of investment in technology and human resources to improve recruitment and selection has invariably led to increase in shareholders ' fund and profitability (profit before tax) of First Bank Plc. over the years, as the investment in technology stepped up the value of shareholders 'funds and profitability of the bank.

The ANOVA analysis of First Bank Plc. implies that it is worthwhile to invest in technology and human resources in order to enhance capability of newly employed staff of First Bank Plc. It further indicates that as technology infiltrates all aspects of banking service, employee empowerment is not only place where sound strategies can improve customer's relationship, but also customers are increasing in accepting automated and systematized communication channels. Touch points such as corporate websites, ATM machine, Help desks are normally part of many customer-initiated business interaction. Well planned recruitment and selection must be leverage in this system.

Table 1

First Bank Plc Performance Indicators (2004- 2011)

\begin{tabular}{|c|c|c|c|c|c|c|c|c|}
\hline Indication & $\begin{array}{l}2011 \\
\#^{\prime} b\end{array}$ & $\begin{array}{l}2010 \\
\#^{\prime} b\end{array}$ & $\begin{array}{l}2009 \\
\#^{\vee} b\end{array}$ & $\begin{array}{l}2008 \\
\#^{`} b\end{array}$ & $\begin{array}{l}2007 \\
\#^{\prime} b\end{array}$ & $\begin{array}{l}2006 \\
\#^{`} b\end{array}$ & $\begin{array}{r}2005 \\
\#^{`} b\end{array}$ & $\begin{array}{r}2004 \\
\#^{`} b\end{array}$ \\
\hline $\begin{array}{l}\text { Gross } \\
\text { Earnings }\end{array}$ & 296.300 & 207.524 & 185.189 & 130.600 & 72.299 & 61.243 & 49.475 & 45.121 \\
\hline $\begin{array}{l}\text { Profit before } \\
\text { taxation }\end{array}$ & 65.600 & 31.491 & 46.110 & 38.020 & 22.079 & 16.053 & 12.184 & 14.106 \\
\hline $\begin{array}{l}\text { Profit after } \\
\text { taxation }\end{array}$ & 50.100 & 26.936 & 35.074 & 30.473 & 16.371 & 16.053 & 12.184 & 11.096 \\
\hline $\begin{array}{l}\text { Shareholder's } \\
\text { fund }\end{array}$ & 380.794 & 350.467 & 351.054 & 339.847 & 77.351 & 60.980 & 44.672 & 38.621 \\
\hline $\begin{array}{l}\text { Loan and } \\
\text { advances }\end{array}$ & $1,128.851$ & $1,017.411$ & 684.107 & 437.768 & 219.185 & 175.657 & 114.673 & 78.040 \\
\hline Investments & 600.886 & 317.073 & 65.336 & 71.532 & 64.048 & 63.729 & 24.655 & 16.825 \\
\hline $\begin{array}{l}\text { Operating } \\
\text { Expenses }\end{array}$ & $(134.786)$ & $(107.392)$ & $(80.880)$ & $(76.116)$ & $(46.484)$ & $(32.068)$ & $(29.486)$ & (26.941) \\
\hline
\end{tabular}

Source: First Bank Annual Report. 
From Table 1, it can be seen that the bank recorded a commendable performance because of good management, hardworking, staff corporation and most importantly the banks emphasis on well planned recruitment and selection processes.

Gross earnings of the bank stood at N296.3 billion in 2011 from N72.299 billion recorded in 2007. This is an improvement of more than 4 folds or $400 \%$.

Profit before tax of N65.6 billion is also an improvement of 3 folds when compared to the figure of N22.079 billion in 2007. Profit after tax totaled N16.371 billion in 2007 to N50.10 billion in 2011 representing an increase of more than $300 \%$ or 3 folds.

Shareholders ' fund of the bank rose to N351.054 billion in 2009 from N77.351 billion in 2007. The improved performance recorded over the years has been attributed to the First Bank well planned recruitment and selection process.

\section{CONCLUSION AND RECOMMENDATION:}

The aim of recruitment goes beyond mere filling of vacancies to include individual development and achievement. It aims to build a strong organisation where effective team work, and the individuals needs are realized at the same time. To achieve this aim, the organisation must re-adopt recruitment policies which are internally consistent and which are also consistent with the objectives of the organisation and the expectations of the larger society.

A good selection process is one that is properly planned and well operated. Poor recruitment efforts could lead to the selection of poor applicants because positions are to be filled too quickly. In addition, poor recruitment and selection process could affect individual development and debars the organization from achieving its set goals and objectives.

It is therefore recommended that for recruitment and selection process to be effective, it should be consistent with an established standard, fair, transparent, and ensures that the right peg is put in the right hole.

\section{REFERENCES}

Boerlijst, G. and Meijboom, G. (1989): (Matching the individual and the Organisation in P. Harriot (ed), London John Wlley and Sons Ltd.

Casio, W.F. (2005): Managing Human Resources: Productivity Quality of Work Life Profits $2^{\text {nd }}$ Ed. New York. Mc Graw-Hill Inc.

Cole, G.A. (2005): Personnel and Human Resource Management Book Power.

Ejiofor, P. (1989): Foundations of Business Administration, Ibadan Africana FEP Publishers Ltd.

Flippo, E.B. (1984): Personnel Management 'Sixth Edition, New York, McGraw-Hill Book Company. 
Ilesanmi, O.A. (1997): Modern Management. Lagos Fapsony (Nig) Ltd.

Ilesanmi, O.A. (2005): Modern Management. Lagos Fapsony (Nig) Ltd.

Nwachukwu, C.C. (1992): Management Theory and Practice. Ibadan. Africana FEP Publishers Ltd.

Shafritz, J.M, Russell, F.W, and Borick, C.P (2007) Introducing Public Administration, (5 Edition) New York Pearson Longman.

Stonner, Freeman \& Gilbert (Jr.) (2000): Management $6^{\text {th }}$ Edition, India Prentice Hall.

Tim Hannagan (1995) Management Concept and Practices, Harlav, Essox Pitman Publishing.

Waynw F. Casio (2002); Managing Human Resources: Productivity Quality of Work Life Profits, $2^{\text {nd }}$ Ed. New York. Mc Graw-Hill Inc.

Weihrich, H. and Koontz H. (1994) Management: A Global Perspective. Tenth Edition, New York McGraw Hill Int. Editions Management Organization Series.

Weihrich, H, Cannice, M.V. and Koontz, H. (2011) Management: A Global Perspective. (13th Edition), New Delhi Tata McGraw Hill. Educational Private Limited Pp. 243-264. 